\title{
Environmental crime and influence of socio- economic factors on the development of punishment system
}

\author{
Konstantin Sych $^{1}$ and Vladimir Sych ${ }^{1, *}$ \\ ${ }^{1}$ Academy of the Federal penitentiary service of Russian Federation, 1 Sennaya str., Ryazan, 390000 , \\ Russian Federation
}

\begin{abstract}
The institution of criminal punishment is a part of the statelegal mechanism of coercive influence on the population to stimulate lawabiding behavior and prevent law violation. The history of Russian criminal law contains more than a thousand years of experience in consolidating this institution of criminal law. At different stages of state development, the system of punishments and other measures of a criminal law nature had significant differences due to various socio-economic, political, historical and other factors. Structural analysis of punishment system of Russian state at different stages of its existence indicates that socio-economic factors affecting the state structure and state policy have a huge impact, both on the construction of punishment system and on its direct implementation. In particular, technological development of society, development of transport system, the need for cheap labor during construction, the general level of development of social relations led to the inclusion of new types of punishments in the legislation or changes in those acting under specific socio-economic conditions (reference to remote settlements, use of forced labor prisoners during construction, etc.).
\end{abstract}

\section{Introduction}

Considering the written sources of law, starting with Russian truth and ending with modern normative legal acts, it is necessary to pay attention to some aspects when building a system of sanctions against violators of legal norms, especially criminal law. In particular, since ancient times, the most important role for the state was primarily played by the extraction of economic benefits from the use of one or another type of punishment, and only then the achievement of social and legal goals. This aspect makes it necessary to analyze the development of institution of punishment in order to identify the factors that influenced it.

A similar trend in the design of Russian punishment system was observed right up to the adoption of current criminal code in 1996, the reform of penitentiary system and the mechanism for execution of punishments. This changed the balance from gaining some kind of benefit towards social benefits. It is obvious that in the modern world, the primary

\footnotetext{
*Corresponding author: vladimirsych@yandex.ru
} 
task is to achieve socially useful goals (restoring social justice, preventing new crimes), rather than deriving economic benefits.

The aim of the study is a structural analysis of development of institution of punishment, factors influencing it, for theoretical and legal conclusions that complement the conceptual foundations of institution of punishment.

To achieve this goal, following tasks were set and fulfilled:

- to conduct a historical-legal and comparative-legal analysis of development of institution of punishment at the legislative level;

- to study the influence of socio-economic factors influencing the development of punishment system;

- to study the degree of influence of socio-economic factors on the institution of punishment at various historical stages.

\section{Methods}

Studies of issues of punishment and other measures of a criminal-legal nature were carried out throughout the entire period of existence of legal science. At the present stage, this issue was considered by many authors, in particular, D. A. Illo studied the tendencies of development of institution of punishment in Soviet law; O.N. Nichugovskaya considered modern problems of punishment system; EA Kadaneva worked on issues related to imprisonment; M.A. Temirkhanov investigated the goals of punishment;

V.N. Orlov conducted a study of use of institution of punishment. However, it is worth noting that the issue of development of punishment system is still relevant, in view of large number of unresolved or debatable questions regarding the institution of punishment.

In the course of this study, various general scientific and private scientific methods of cognition were consistently applied.

\section{Results}

The study showed a direct dependence of current punishment system not only on the development of the state and its legislation, but also on a number of socio-economic factors. At the present stage of state development, the achievement of socially significant goals facing the institution of punishment significantly prevails over economic ones. Thanks to this, in the Russian Federation it was possible to achieve a significant decrease in the number of persons held in correctional institutions, in comparison, both with the Soviet period, and in comparison with other states (Fig. 1).

The institution of criminal punishment is a part of the state-legal mechanism of coercive influence on the population to stimulate law-abiding behavior and prevent law violation. The history of Russian criminal law contains more than a thousand years of experience in consolidating this institution of criminal law.

It is known that in the early stages of state development, there were no positive legislation and punishment, they were replaced by religious concepts about sin and retribution for it. For the most serious offenses, the injured party had the right, based on social tradition, to private revenge.

The first normative legal act that has come down to us - Russkaya Pravda, established a complex system of punishments: virginity, lesson, bravado, flood and plunder. All of them, one way or another, were of a property nature.

Let's consider this system in more detail. Vira provided for the payment of a monetary fine in favor of the prince for the murder of a free person and persons of the princely administration, for cutting off an arm, leg, nose, gouging out eyes; for the murder of the 
"princely husband" a double vira was charged - 80 hryvnia, for the murder of a servant vira was not provided.

Table 1. The number of persons held in correctional facilities, per 100,000 people.

\begin{tabular}{|c|c|c|c|}
\hline № & The country & Prisoners per 100,000 [12] & Prisoners total [13] \\
\hline 1 & USA & 639 & 2094000 \\
\hline 2 & Salvador & 572 & 38114 \\
\hline 3 & Turkmenistan & 552 & 30452 \\
\hline 4 & Palau & 522 & 94 \\
\hline 5 & Rwanda & 511 & 65000 \\
\hline 6 & Cuba & 510 & 57337 \\
\hline 7 & Maldives & 499 & 1852 \\
\hline 8 & Thailand & 488 & 381454 \\
\hline 9 & Virgin Islands (UK) & 447 & 143 \\
\hline 10 & Bahamas & 442 & 1778 \\
\hline 24 & Uruguay & 337 & 11755 \\
\hline 25 & Turkey & 335 & 281094 \\
\hline 26 & Russia & 334 & 486031 \\
\hline
\end{tabular}

Let's consider this system in more detail. Vira provided for the payment of a monetary fine in favor of the prince for the murder of a free person and persons of the princely administration, for cutting off an arm, leg, nose, gouging out eyes; for the murder of the "princely husband" a double vira was charged - 80 hryvnia, for the murder of a servant vira was not provided. There was also a wild or indiscriminate vira, they were imposed on the community, if, when committing a murder in robbery, it refused to look for the culprit, it was possible to pay vira in installments. Holovniki - payment to the relatives of the murdered person for refusing to take revenge. Vira gave the legislative basis for this type of criminal punishment as a fine.

\section{Prisoners per 100,000}

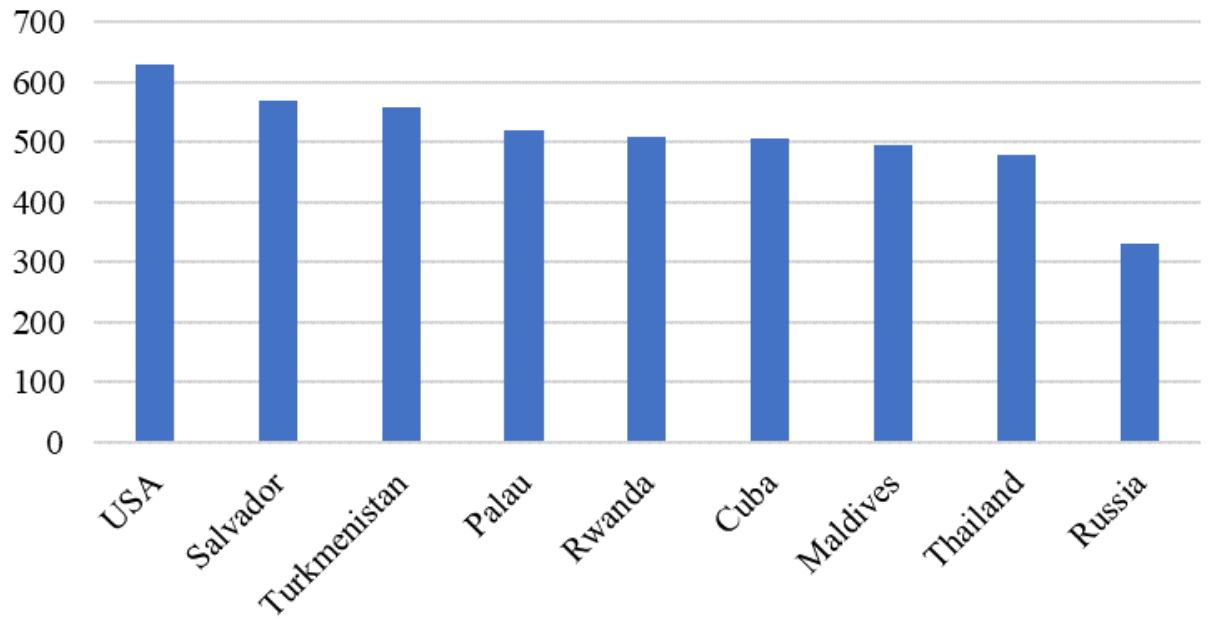

Fig. 1. The number of persons held in correctional facilities, per 100,000 people.

The sale (in favor of the prince) and the lesson (in favor) of the victim were monetary penalties from the person convicted of crimes, with the exception of murder. The amount of the sale was set: 12 hryvnia - for the murder of a thief without demanding defense, insult to honor, imprisonment, theft of a slave and good, for the extermination of a horse and cattle; 
3 hryvnia - for other crimes. The lesson was defined only in relation to personal crimes that caused physical harm.

\section{Discussion}

In the case of financial insolvency of a perpetrator, as well as for a number of crimes (murder in robbery, arson, horse-stealing), this type of punishment was envisaged as flow and plunder. The flow was understood as the deprivation of all personal rights of a guilty person, under the plunder of property. This type of punishment arose under the influence of Greco-Roman system of law, in special legal literature it is defined as the confiscation of all property of a guilty person and his imprisonment in the cellar. The death penalty is not mentioned in Russkaya Pravda.

Based on this, we can conclude that in the early stages of development of Russian statehood, the main direction of criminal punishments was of a property nature, and first of all, payments were made to the prince's treasury from a perpetrator or his community. In our opinion, this was due to both purely economic reasons and social functions. First of all, fight against the remnants of the past (blood feud, lynching).

The next stage in the development of Russian criminal law is associated with the period of formation of Moscow state. It is characterized by tougher punishments and establishment of a mechanism of intimidating influence on the population. Punishment in this period of the history of criminal law is increasingly acquiring features of social intimidation.

It should be noted that the period under review is characterized by two epochs of development of legislation, the era of judicial codes and the era of legal codes.

In particular, in the era of judiciary, the trend of intimidating influence is strengthened and becomes one of the main principles of punishment: qualified types of executions, selfinjurious, painful and shameful punishments. In addition to the death penalty and corporal punishment, which were of priority importance, imprisonment was also introduced as a form of criminal punishment.

The Cathedral Code of 1649 included the norms of various branches of law (criminal, administrative, civil). The criminal law provisions were contained in various chapters of this document. Although the death penalty was provided for by law in 60 cases, corporal punishment was still in the forefront of punishment system.

The mentioned law contains an indication of specific types of self-mutilating punishments: cutting of hands, feet, fingers, ears, tongues. It was with the adoption of the Cathedral Code of 1649 that corporal punishment became widespread, and self-mutilating punishment became a priority even in relation to the death penalty. Cutting with a whip and batogs was one of the main types of corporal punishment, so the use of a whip was provided in 141 cases. The peculiarity of these types of punishment was that they caused not only severe physical pain, but also left "eternal" marks on the human body. The number of blows was not prescribed in the law, they were appointed by the judge, and often the number could reach several hundred, which in practice meant the inevitable death of a perpetrator. From this it follows that this type of punishment was not much different from the death penalty.

However, the Military Regulations of Peter I were even more rigid than the Cathedral Code. The death penalty, in particular, was provided for in 200 articles. At the same time, qualified types of the death penalty were introduced: burning at the stake, hanging, shooting, filling the throat with metal, quartering, wheeling.

Following the historical traditions laid down in the Cathedral Code, the Military Regulations allowed the widespread use of corporal (whipping, shackling in iron) and selfmutilating punishments (cutting off the limbs, tongues, noses, ears). A punishment was also introduced, borrowed from German law - shpitsruten. The procedure consisted in the 
passage of guilty soldiers through the formation, who were his gauntlets on the back. This type of punishment was not disgraceful and after its application a soldier could continue to serve.

At this stage, preventive functions of punishment by intimidating the population had some priority. This was due to the level of social and state development. First of all, there was no need for cheap labor from among the convicts, since this niche was occupied by serfs. And general level of economic, technical development, transport infrastructure did not provide an opportunity to benefit. At the same time, intimidation of population, by means of cruel and self-injurious punishment, had the most important social function of preventing new crimes. These circumstances fit well into the public consciousness of people of that time and corresponded to the historical era.

As noted, early development of state and law, economic relations, technologies and means of production, as well as the ideas of great philosophers, entailed the need for recognition of natural rights, humanization of criminal legislation. This, in turn, made it possible to use convicts more widely for economic purposes. At the same time, the frightening goals of criminal legislation did not lose their dominant importance, despite the departure from corporal and shameful types of punishment, a noticeable reduction in the death penalty. This was reflected in the Code of Criminal and Correctional Punishments of 1845. For the first time in Russian criminal law, the principles of excessive cruelty towards persons who committed crimes were changed towards a humane attitude.

The Code of 1845 was a significant step towards the humanization of criminal legislation, recognition of universal human rights for criminals.

A feature of subsequent criminal laws is their further humanization, so the Criminal Code of 1903 abolished one of the main methods of influencing criminals - corporal punishment, and also significantly reduced the possibility of using the death penalty. This suggests that legislators for the first time in the history of Russian law refuse the concept of intimidation and excessive cruelty in the execution of punishment, the object of influence is the freedom of an individual. The following types of punishments were envisaged related to the impact on personal freedom: hard labor, exile to a settlement, imprisonment in a correctional house, imprisonment in a fortress, arrest.

The October Revolution and the coming to power of the Bolsheviks, as is known, led to the emergence of so-called socialist state, which was proclaimed.

This circumstance, in our opinion, is due to a number of both objective factors, such as the civil war, two world wars, crop failures, and subjective factors inherent exclusively to the Soviet state and communist ideology.

It should be noted that this approach to the institution of punishment, as well as the system of other measures of a criminal-legal nature, has shown its extremely low efficiency, both in terms of economic factors, in view of the low benefits of forced labor, and in terms of moral and social factors.

After the collapse of the USSR and socio-economic transformations in 1996, the Criminal Code of Russian Federation was adopted. In the Criminal Code of Russian Federation in 1996, at the moment, 13 types of punishment have been found (fine; deprivation of the right to hold certain positions or engage in certain activities; deprivation of a special, military or honorary title, class rank and state awards; compulsory work; correctional labor; restriction on military service; restriction of freedom; forced labor; arrest; detention in a disciplinary military unit; imprisonment for a specified period; life imprisonment; death penalty). 


\section{Conclusion}

As of January 1, 2021, there were 482,888 people in the institutions of penal system. (41,040 people by 01.01 .2020 ), including:

- 376471 people served their sentences in 673 correctional colonies.

(-47 354 people), including:

in 107 colonies-settlements, 29,747 people were serving their sentences. (-3 468 people);

in 7 correctional colonies for those sentenced to life imprisonment and persons for whom the death penalty by way of pardon was replaced by imprisonment, 1,967 people were serving their sentences. (-45 people);

- in 209 pre-trial detention centers and 86 rooms, functioning in a pre-trial detention center, held - 104220 people. (+6 439 people);

- 1248 people were serving their sentences in 8 prisons. ( +81 people);

- in 18 educational colonies for minors - 949 people. (-206 people).

There are 39,523 women $(-2,838)$ in institutions, including 30,215 - in correctional colonies, medical correctional institutions, treatment-and-prophylactic institutions, educational colonies and 9,308 - in pre-trial detention centers and premises operating as a pre-trial detention center.

As can be seen from the above data, there is a tendency towards a decrease in the number of persons held in correctional institutions. This is due to the expansion of use of punishments not related to imprisonment, the decriminalization of a number of offenses and other factors. However, it is worth noting that the number of people in custody is still quite high, therefore, the study of the institution of punishment and the impact on its development of various socio-economic factors remains relevant.

\section{References}

1. D.A. Illo, Basic trends in the development of institution of punishment in the Soviet criminal law: author. dis. ... Ph.D. of legal sciences (Ryazan)

2. O.N. Nichugovskaya, The system of punishments in modern Russian criminal legislation: problems and development prospects: author. dis. ... Ph.D. of legal sciences $(\mathrm{M})$

3. E.A. Kadaneva, Deprivation of freedom as a criminal legal institution and prospects for its development: author. dis. ... Ph.D. of legal sciences (Ryazan)

4. M.A. Temirkhanov, Purpose of punishment and the process of punishment: author. dis. ... Ph.D. of legal sciences (Ryazan)

5. V.N. Orlov, Application and serving of criminal punishment: author. dis. ... doc. jurid. sciences (M.)

6. M.F. Vladimirsky-Budanov, Review of the history of Russian law

7. V.I. Sergeevich, Lectures on the history of Russian law

8. Legislation of the X-XX centuries: in 9 volumes. Vol. 3 (M., 1985)

9. Legislation of the $X-X X$ centuries: in 9 volumes.Vol. 4 (M., 1986)

10. Legislation of the $X$-XX centuries: in 9 volumes. V. 9 (M., 1986)

11. Federal Service for the Execution of Punishments, https://fsin.gov.ru

12. The World Prison Brief, https://www.prisonstudies.org

13. The World Prison Brief, https://www.prisonstudies.org 
14. V. Lez'Er, N. Semerianova, A. Kopytova, Y. Truntsevsky, E3S Web of Conferences 110, 02093 (2019) DOI: 10.1051/e3sconf/201911002093

15. V. Lez'Er, N. Semeryanova, A. Kopytova, I. Kvach, E3S Web of Conferences 110, 02094 (2019) DOI: 10.1051/e3sconf/201911002094

16. Y.V. Truntsevsky, I.I. Lukiny, A.V. Sumachev, A.V. Kopytova, MATEC Web of Conferences 170, 01067 (2018) DOI: 10.1051/matecconf/201817001067

17. N. Semeryanova, O. Fedorenko, A. Kopytova, MATEC Web of Conferences 239, 04013 (2018) DOI: 10.1051/matecconf/201823904013

18. M.S. Gusarova, A.V. Kopytova, I.G. Reshetnikova, Periodico Tche Quimica 16(31), 903-912 (2019)

19. Y. Truntsevsky, V. Lez'er, S. Belyasov, A. Kopytova, E3S Web of Conferences 157, 03016 (2020) 